\title{
A Comparative Study of Local Financial Autonomy in Italy, France and Morocco
}

\author{
Meryem Ait Ouali \\ Mohamed Boussetta \\ laboratory of studies on Entrepreneurship and Public Policy, \\ Faculty of Economic and Social Legal Sciences, Kenitra, \\ University Ibn Tofail, Morocco
}

Doi: 10.19044/esj.2017.v13n34p151 URL:http://dx.doi.org/10.19044/esj.2017.v13n34p151

\begin{abstract}
Financing local communities relies on a complex network of taxes, subsidies and loans. In the last decade the network has undergone numerous transformations.The reforms implanted in past years changed the systems of public finance substantially. Therefore, financial local autonomy is a term that frequently employed in the literature of federalism and decentralization, but it's rarely defined conceptually in a careful way to empirical research. Generally it expresses the capacity of local communities to have their own revenue and expenditure budget, distinct from that of the state in which revenue can cover expenses incurred to meet their requirements. Indeed it is a highly valued feature of good governance.

This paper is dedicated to a study in theory and practice. Starting with an overview on background of theoretical approach of local financial autonomy, then comparing the experiences of two European countries France, Italy and Morocco in the field. The purpose of this paper is to clarify the meaning of local financial autonomy and give a structured overview of the factors that may potentially influence the liberty of sub national authorities with regard of their own revenue and expenditure budget. Based on indicators and taking into account empirical evidences offered by official statistical datas, established in recent years for evaluating the position of administrative territorial units in relation to central government. The analyses prove that there is no universal model of local public finance applicable to all countries, because each has its own specific historical, cultural and linguistic particularities.
\end{abstract}

Keywords: local budget, public expenditure, local financial resources, local communities. 


\section{Introduction:}

There has been a recent and engaging debate around administration management, organization structures and public policy that exist in an environment of complexity. One of the major topics is fiscal decentralization, which supported by the growing importance of the concept of decentralization, the latter can be defined as a two-dimensional policy, the levels of freedom both of (government, national, regional, local, etc...), and the amount of discretion given to regional and local governments to determine their expenditures and revenues. It means government decisionmaking and implementation responsibilities in public finance redistributed to lower levels of government fiscal autonomy upward toward.

In other words, The degree of the fiscal decentralization characterizes the level of freedom of local government, where local government is independent as much as it has financial resources to fulfill its functions (Davulis, Peleckis, Slavinskaite, 2013), also to ensure their own expenses and at the same time to achieve the decentralized powers with the help of local public, this requires that local governments must control their own sources of revenue in order to reach enough financial fiscal autonomy and accountability to their local tax payers.

In this paper, we decided to compare local financial autonomy in Italy, France and Morocco because we are already familiar with these three cases, which is useful for an exploratory research. In this case, our framework raises several questions: should financial autonomy be measured by the ability to freely decide the nature of its income and expenditure? Just as, what are the factors that can limit it?

We first present briefly the theoretical level, which is intended to highlight the theories of local financial autonomy and a presentation of local organization structure of each country, followed by a empirical part of this study which is achieved through the local budget indicators, conducted in France, Italy and Morocco; the paper ends with conclusions and references.

\section{I- Local financial autonomy in theory}

Local finances have become an economical and political issue in Europe and Morocco. They are the subject of a major question on the financial autonomy of local authorities, regardless to decentralization of a country. Indeed the financial relations between the State and its communities are multiple and very complex, it reflects at the same time the conflictual nature of the financial aspects of the regionalization. However, the three countries are unitary states that come to exist to protect diversity and unity. In fact, these cases also show differences in the level of the evolution of their public organization. 
In this perspective, most states have enshrined in the Constitution or the law the principles of free administration and financial autonomy of local authorities. In accordance with the European charter, who was the first documents to defined the local self-government, adopted in 1985 and ratified by 45 member states of the council of Europe, defined the local SelfGovernment as the right and the ability of local authorities, within the limits of the law, to regulate and manage a substantial share of public affairs under their own responsibility and in the interests of the local population.

Indeed, the notion occupies a central position in the literature on political and fiscale decentralization. Obviously, it has something to do with the freedom of sub-central government units to manage their affairs in a way that is not entirely dictated and controlled by the central government. There are multiple definitions of local autonomy or the local self-government; in terms of politics this concept defines as the government's ability to have an independent impact on the welfare of the residents of the local jurisdiction.

In its most general conception, financial autonomy depends not only on legal issues but also economic ends; it implies the freedom to choose the source, the amount and the allocation of resources between the different financial categories. It can take the form of the provision of sufficient resources to guarantee the free determination of its expenditure and also the exercise of decentralized competences. However, it will not be useless to recall the definition of André ROUX which emphasizes in this regard "Financial autonomy has a double dimension. Firstly, it is the recognition of a legal decision-making power which, in terms of revenue, implies a real fiscal power, the power to create and levy the tax and which in terms of expenditure implies the freedom to decide allocate resources to one or other expense. Secondly, it is the possibility for regional or local authorities to ensure the financing of their expenditure by own resources in sufficient volume".

In a financial term, local autonomy implies the right of local authorities to have enough resources, and use them to perform the duties prescribed by law, to elaborate budget, to monitor the implementation of budget sometimes called financial autonomy (Voinea, 2001). We note that such a definition would require local authorities to decide absolutely free on local revenues and expenditures reflected in the local budget, in other words, the guarantee to have stable and enough resources that allows the local community to exercise fully and relevant the decentralized competences. In these circumstances, to support their competences at a cost, local authorities must identify their sources of income and to prepare expenditure programs. In this context, autonomy in financial terms can be defined by combining three elements (Guengat and Uhaldeborde, 2003; Gilbert, 1999): local expenditure autonomy, local revenues autonomy and budget autonomy. 
Local revenue autonomy implies the right and ability to finance independently, and according to the local preferences, the plan of delegated expenditures approved by the voters determines the types of taxes. It is often considered that the tax autonomy measures the weight of own-source tax revenue, local revenue included the freedom to decide about the redistributive character of local taxes and fees as well as about the way the revenues are used.

Local expenditure autonomy is in one hand, the freedom to decide the nature of goods and services that should be financed from the local public budget and how much funds should be spent on each of them. On the other hand, expenditure autonomy also includes the freedom to decide how these goods and services should be produced or delivered. Finally, local budgetary autonomy is the freedom to act simultaneously on both the revenue and expenditure side of the budget in order to avoid or correct vertical fiscal imbalances. It implies the ability of local authorities to adjust the income level of public spending. It gives the right to local authorities to achieve a statistically and dynamically budget over which assumes financial responsibility.

\section{II- The local organization structure}

In France, the public structure in France has a long history of centralization; the past 20 years have brought some radical changes .At first sight, the system may seem complex. France is one of the few countries in the European Union with four tiers of government; the central government, region, department and commune.

The decentralization law of 2 march 1982 and the legislation tried to balance power between the state and local authorities. It gave greater autonomy in decision-making by sharing administrative and budgetary tasks between central and local authorities.

The role that the local authorities were to play in shaping democratic was at that time considered to be great. The recreation of local governments was one of the first fundamental reforms undertaken. The autonomous local governments were created to help stabilize the new democracy through political, fiscal and administrative decentralization. It was considered vital to have local governments as allies in the struggle for strengthening and stabilizing the democratic system in France during the time of system transformation in the early 1958.

In Italy the institutional framework territorial government breaks down into four layers. Sub-national governments comprise: 20 regions, 103 provinces and 8,100 municipalities. The Constitution dedicates all of Title $\mathrm{V}$ (Articles 114-133) to them, as well as the first phrase of Article 5, which recognizes and promotes local autonomy. Article 114 considers these 
territorial bodies together with the state as the constitutive elements of the Republic, moreover, the Constitution provided with legislative and administrative powers, particularly relevant in the fields of agriculture, commerce, public health, tourism, public works and long-distance public transport.

There are Five special Regions: Sicily, Sardinia ,Trentino Alto Adige, Valle d'Aosta, Friuli Venezia Giulia, were established between 1949 and 1964, to reduce the threat of separatist movements and ethnic tension. They have far wider competences for instance in education and the promotion of industrial activities, than other 15 ordinary statute regions, which became operational only in 1970.

Finally, in Morocco the $3^{\text {rd }}$ of January 2010, king Mohamed VI announced in a speech to the nation the creation of the consultative committee on regionalization (CCR), with the objective of entrusting this organ with the task of preparing a project that is going to be the fundamental future plan of decentralization based on giving the local authorities more autonomy. The proposal for advanced regionalization starts with a plea for the optimization of financial resources, and the local authorities should be more involved in the management of their issues.

Local authorities in Morocco are legal entities of public law, who democratically manage their affairs, the distribution of responsibilities among different levels of government is clearly defined by law but the financial autonomy of local government is still limited. However, administered by elected councils, the regions, prefectures/ provinces and municipalities (communes) are legal entities with their own budgets.

\section{III- Empirical study results}

The comparative analysis of local financial autonomy in two European Union countries and Morocco suggested a diversity of national rules. However, each country has it way to manage and controls his local finance.

\section{III-1 Revenue autonomy}

The autonomy of management of resources corresponds to the leeway available to the local authorities to finance their expenses; this autonomy can be exercised only within the framework of the constitution and the law. Most of the resources of local authorities are tax revenues, because they can use the tax system to cover their expenses, to invest and finance the current services of their territory (schools, transport, and social assistance).

In Italy, budget analysis show local government revenue accounted for $14.9 \%$ of GDP in 2014 of public revenue (table 1), the majority of revenue comes from taxes, the latter presented in 2014, approximately $65 \%$ of local revenue. 
Table 1. Local revenue as \% of GDP in France and Italy over the period 2007-2014

\begin{tabular}{|l|l|l|l|l|l|l|l|l|}
\hline Country/year & 2007 & 2008 & 2009 & 2010 & 2011 & 2012 & 2013 & 2014 \\
\hline France & 10.6 & 10.7 & 11.6 & 11.4 & 11.4 & 11.5 & 11.5 & 11.6 \\
\hline Italy & 14.6 & 14.9 & 16.4 & 15.3 & 14.8 & 15.5 & 15 & 14.9 \\
\hline
\end{tabular}

Source: Euro stat

In fact, the local system has undergone a profound mutation last years; a new municipal property on real estate has been introduced. The tax is levied by municipalities that have the power to fix the tax rates between relatively wide brackets determined by the central government. The income for Italian municipalities that derives from this tax has considerably increased in recent years, according to Bankitalia's figures, in 2014 the taxation system of municipal revenues managed to reach 19.79 billion $€$, against 8.89 billion $€$ in 2009 (Figure 1) derived from real estate taxes (IMU e TASI) .

Figure 1: Italian municipal authorities revenue from property tax from 2009-2014 in billion€

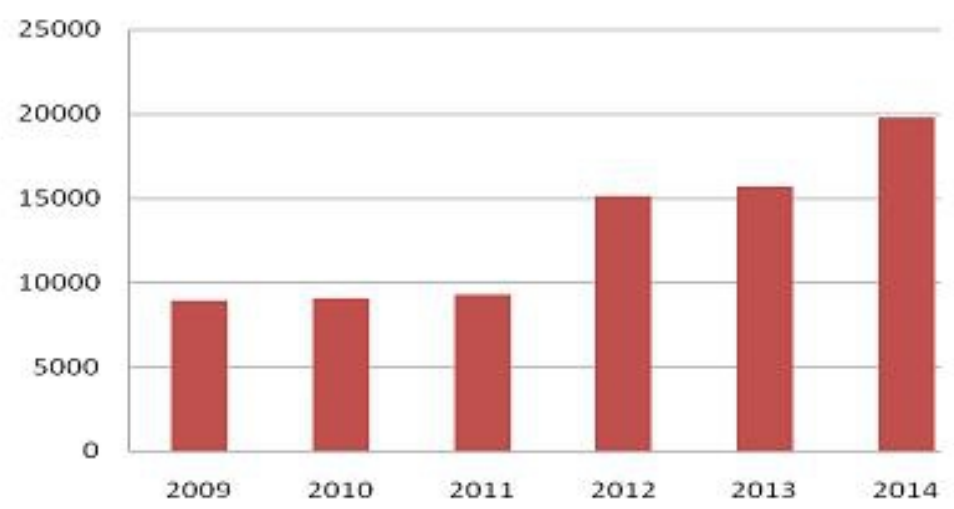

Source: Bank of Italy

Moreover, the major step of regional tax autonomy has taken place after the introduction of a direct-type value-added tax (IRAP, regional tax on business activities) to be levied on all business activities. Regional governments have been constrained to levy a centrally-set uniform tax rate of 4.25 per cent, $4.2 \%$ for banks and financial entities, and $5.3 \%$ for insurance corporations. 90 per cent of revenue from IRAP like whole revenue from the basic surtax on income is earmarked to finance the National Health Service. This partially limits the fiscal autonomy and accountability of the region.

In France, the analysis of the budget of local authorities showed a great diversity of revenue to local government, furthermore, in correlation with GDP, local revenue in France accounted for $11.6 \%$ of public revenue in 2014 (table no.1) ,show the importance share of local authorities compared to the state. 
This importance has been given by the constitutional law of 28 March 2003 article 72-2 states that: local authorities have resources which they may dispose freely in the conditions fixed by law. They may also receive total or part of the produce of taxes of all kinds. Furthermore the law can allow fix the base and rate. Tax revenue and other own resources of territorial communities represent for each category of communities, a decisive share of all of their resources. Own resources consist of: the proceeds of taxes of all types which law allows local authorities to secure the base; rate or tariff; charges for services rendered, products of the field; town planning holdings, donations and legacies and financial products.

Regionalization, through its different phases, has given local authorities multiple competences and increasing responsibilities. Indeed, even before the revision of the constitution, a legal principle of financial compensation for the transfer of powers already existed, included in the general code of local authorities. This revision made it possible to complete this principle by stipulating that not only the powers transferred by the State but as well the new powers that were not previously exercised by the State.

This principle was introduced in 2010 by the law of finance, and put in place from the year 2011. In order to fully compensate for the shortfall, through a compensation relay, whose modalities are specified.

In addition, financial transfers from the state to local authorities allow financing their current operation (global operating grant DGF) and investments including their equipment and infrastructures. State's grants offset the expenses generated by the transfer of powers to local authorities in the context of decentralization, but also exemption from local taxes determined by the state. The overall operating grant established by the law 3 January 1976, it is the main endowment and the pivot of the financial relations between the State and the local authorities. It consists of a levy made on the budget of the State paid to the local authorities, in order to modernize the conditions for granting state subsidies, it includes 12 grants (2 for the regions, 4 for the departments, 2 for the EPCI, and 4 for the municipalities).

The financial autonomy in France is often linked to a fiscal autonomy and especially the freedom of setting the tax rate. Since 2010 reforms have been proposed at the level of local taxation, it's about the removal of professional tax and replaces it with the territorial economic contribution (CET), This new contribution is made up of two elements: the company land contribution (CFE) and the company value added contribution (CVAE). The redistribution thus of taxes between levels of government reform has created fears, especially as it brings 30 billion $€$ according to DGCL, only $65 \%$ are offset by tax revenues, with the remainder allocated grants by the state. Also local election's voting rate of $30 \%$ of the new tax, 
while they were voting the rate of the entire tax professional before, which reflected loss of fiscal freedom in setting rates.

Briefly, since the abolition of the business tax, the fiscal and financial autonomy of local authorities has been considerably reduced, contrary to what the autonomy ratio defined by organic law n ${ }^{\circ} 2004-758$ of 29 July 2004 pursuant to Article $72-2$ of the Constitution. At the same time as local authorities have lost a significant part of their freedom in setting tax rates, replacing them with state grants to compensate losses of materials of local recipes.

In Morocco, according to official statistic (TGR), local authority's resources increased in 2014 to get 31.9 billion dirham against 31.7 in 2013 and 28.7 in 2012, this can be justified by the rise of transfers of grants by the state to local authorities, which accounted in 2014, 63\% of overall local resources, (table 2).This increase resulted from the rise of the share of local authorities in the product of VAT $55.8 \%$.

Table 2: Local authority's resources in Morocco over the period 2011-2014 in billions dirham

\begin{tabular}{|l|c|c|c|c|}
\hline $\begin{array}{l}\text { Nature of } \\
\text { resources /year }\end{array}$ & 2011 & 2012 & 2013 & 2014 \\
\hline Transferred & $\mathbf{1 8 ~ 7 0 8}$ & $\mathbf{1 7 ~ 7 7 0}$ & $\mathbf{1 8 ~ 8 8 0}$ & $\mathbf{2 0 ~ 3 9 7}$ \\
\hline $\begin{array}{l}\text { Managed by the } \\
\text { state }\end{array}$ & $\mathbf{4 6 2 2}$ & $\mathbf{4 9 6 0}$ & $\mathbf{5 9 2 9}$ & $\mathbf{4 9 1 7}$ \\
\hline $\begin{array}{l}\text { Managed by local } \\
\text { authorities }\end{array}$ & $\mathbf{5 8 1 9}$ & $\mathbf{6 2 8 2}$ & $\mathbf{6 9 8 7}$ & $\mathbf{6 5 9 7}$ \\
\hline Total & $\mathbf{2 9 1 4 9}$ & $\mathbf{2 8 ~ 7 4 2}$ & $\mathbf{3 1 7 9 6}$ & $\mathbf{3 1 9 1 1}$ \\
\hline
\end{tabular}

Source: TGR

On the other hand, own resources reached 11.5 Billion dirham in 2014. These revenues consist of resources managed by local authorities $(20 \%)$ and other managed by the state on behalf of local authorities (15\%).Resources managed by local governments reached 6.5 billion dirham in 2014 and consist mainly local taxes (52\%), products of services $(28.6 \%)$ and property income (19.9\%).

The resources managed by the state reached 4.9 billion dirham in 2014, these resources based on tax communal services (over 53\%), and professional tax (36\%). Indeed, tax revenues reached 27 billion dirham; they represented $84.7 \%$ of total revenues of local authorities during 2014.which show the important share of taxes in local revenue.

It should be noted that despite the evolution of revenues in Morocco, the local authority's finances are suffering, from the inadequacy of their own resources, which makes them dependent on the financial support of the State, and the allocated financial resources are under exploitation, marked by the availability of unused surpluses. 


\section{III-2 Spending autonomy}

The constraints of the financial autonomy of the locales authorities are only observed at the level of the resources of the communities, but also on their expenses. Indeed the decisional freedom of expenditure is limited by two constraints; on one hand compulsory expenditure and, on the other, regulated or prohibited expenditure.

In France, the new competences transferred by the state to local authorities have led to an increase in expenditure; it represented $29 \%$ of overall public spending in 2014 (figure 2.) Moreover operating expenses are the most important, they relate to the current operations of local authorities. In 2014, they represented approximately $70 \%$ of total expenditures. Furthermore, investment expenditures relate to capital transactions. They are about $30 \%$ of total expenses. Consist of property and equipment acquisitions and equipment works.

According to OECD, expenditure on education in 2014 represented $14 \%$ of local budget, social protection $18 \%$, health care $0.7 \%$, general public service $17 \%$, economic affairs $19 \%$ and housing and community amenities expenditure $14 \%$.

Figure 2: Share of local authority's expenditure of overall public spending (\%) in 2014.

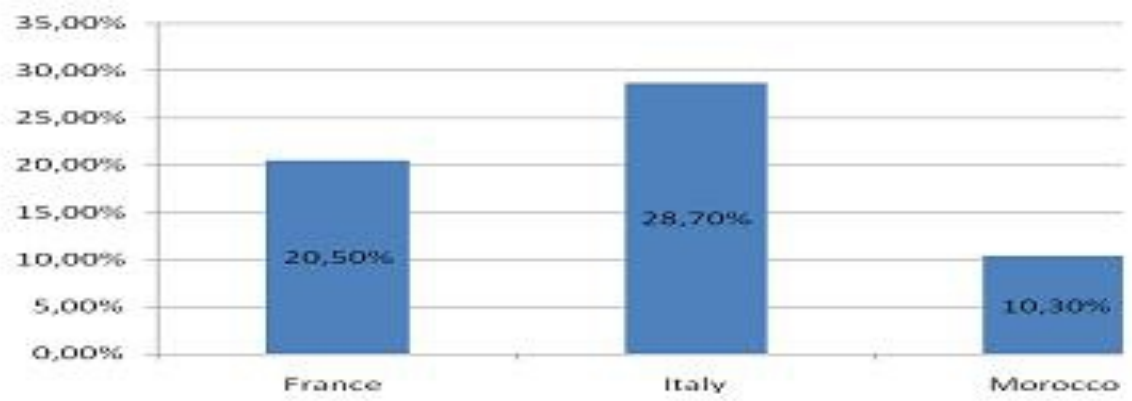

Source: OECD, TGR, 2014

In 2014, Italian local authority's expenditures represent $28.7 \%$ of overall public spending Figure 2. Indeed new competencies were transferred to regions and local government especially healthcare which account almost half of local expenditure in volume terms $47.0 \%$ in 2014 , education $6.8 \%$ of local budget, housing community amenities $18.3 \%$, and economic affairs $44.8 \%$.

In Morocco, despite the increase in the share of local authority's expenditures, it never exceeded $11 \%$ of public expenses. In 2014, expenditure of local authorities was 31.6 billion dirham, the operating expenditure represent the major part of local authorities expenditure with $66 \%$, they are composed mainly of personnel expenses, expenditures of goods and services 28\% and the charges for the debt account $3 \%$. While the 
investment's expenditure wasn't exceeding $34 \%$ of local authority's expenditures (Figure 3).

Figure 3: Local expenditure by economic function in Morocco

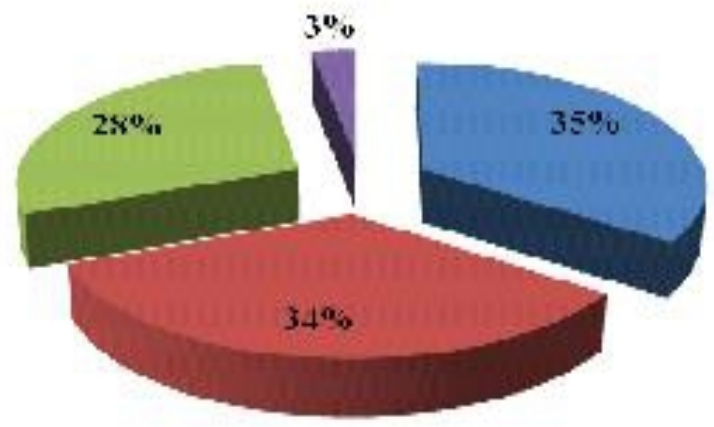

- Fetsonal expenses

- Investiment

Equipment

$=1)+\ln ($ int $1+1 \cdot 2 \times 1$

Source: TGR

\section{III-3 Budget balance}

In France, local budget deficits registered $0.2 \%$, in 2014. This is due to many reasons; we must first underline the weak growth of revenue raised by communities, which could offset the rate of spending. Public accounting distinguishes expenses / operating revenue and investment. In both cases, expenses are rising faster than revenue, widening the deficit. Also one of the reasons the reduction of the transfers from the central government in 2014. As well as revenue from indirect and local taxes were not enough to restore the balance.

Although the improvement in the budget balance over the period 2011-2013 has resulted from the brightening economic backdrop in many countries - which has boosted tax revenue - as well as budget consolidation efforts by local authorities (optimization of own-source revenue and cost controls). It is also due to strengthening management and oversight of local government finances under national fiscal improvement measures. The deficit being progressively reduced from $0.1 \%$ of GDP in 2011 to $0 \%$ in 2012 and 2013. In France, local authorities have sufficient resources to effectively exercise their powers.

In Morocco, the situation of expenses and resources of local authorities showed a surplus of 4.3 billion dirham at the end 2014 against a surplus of 4 billion dirham a year earlier. The investments credits are rarely consumed, despite the increased need for infrastructure. 


\section{Conclusion}

The main aim of this paper is to present an exploratory comparison of the degree of local financial autonomy between France, Italy and Morocco. After having shown the similarities and differences of the three cases, we had used the empirical evidences to explore how financial autonomy depends on revenue, expenditure and budget autonomy, have impact on local autonomy. Despite the constitutional guarantees of their financial autonomy, local authorities have only a relative financial freedom. In one hand, their decision-making in financial matters is very limited and the control exerted on their decisions is small, on the other hand, they lack of their financial resources or control of their financial matters. However, financial autonomy requires the availability of sufficient resources to exercise their powers. But also the freedom to choose their management methods, to distinguish and execute their expenses, to determine the level and types indebtedness, and to act on the level of their revenues. The study confirmed also that there is no universal model of local finance, because each country has its particularities (which can include, cultural, historical, political, and the size of the territory).

\section{References:}

1. Article 3 para. 1 of the European Charter of Local SelfGouvernement, adopted in Strasbourg on (October 15,1985).

2. Council of Europe, European Charter of Local self-government, adopted in Strasbourg on October 15, (1985), art.3.

3. Curzon Price V \& Garello J.(2003). Index of Fiscal decentralization: methodology and finding, In Journal des Economistes et des Etudes Humaines, 13(4):441-478.

4. Ebel R \& Yilmaz S.(2002), on the Measurement and Impact of fiscal Decentralization", Policy Research Working paper 2809 , the World Bank, Washington D.C.

5. Fleurke, F \& Willemse , R. (2004). Approaches to decentralization and Local Autonomy: A critical appraisal, 26 (4): 523-544.

6. Gevart P.(2006). Comprendre les enjeux de la décentralisation, l'etudiant:36.

7. Gordon C. (1984). ATheory of Local autonomy, Annals of association of American Geographers, 74(2):195-208.

8. Hertzog R. (2003). L'ambiguë constitutionnalisation des finances locales, Actualité juridique - droit administratif : 548.

9. Kurti T. (2014). Financial System and Local government in European countries, European scientific Journal, 1:543-547.

10. Malo M \& Nas P. (1991). "Local Autonomy: Urban Management in Indonesia”, Sojourn, Vol.6, No.2:175-202. 
11. Pratchett L.(2004). "Local Autonomy, Local Democracy and the New localism', Political Studies, 52(2) :358-375.

12. Roux A . (2006). l'autonomie financière des collectivités locales en Europe, rapport introductif, annuaire internationale de justice constitutionnelle :499

13. Rusu E.(2014). Comparing local financial autonomy across the European Union. Advanced research in scientific areas, 1(5):153-159.

14. Torgler, B \& Schneider, F.: Schaltegger, C. (2010), Local Autonomy, tax morale, and the shadow economy, Springer, 144(1/2): 293-321. 